\title{
Modelling the activation of neuronal populations during deep brain stimulation

\author{
Nuri Purswani ${ }^{1}$, Nada Yousif*2 and Xuguang Liu ${ }^{2,3}$
}

\begin{abstract}
Address: ${ }^{1}$ Department of Bioengineering, Imperial College London, London, UK, ${ }^{2}$ Department of Clinical Neuroscience, Imperial College London, London, UK and ${ }^{3}$ Movement Disorders and Neurostimulation Unit, Charing Cross Hospital, London, UK

Email: Nada Yousif* - n.yousif@imperial.ac.uk

* Corresponding author
\end{abstract}

from Eighteenth Annual Computational Neuroscience Meeting: CNS*2009

Berlin, Germany. 18-23 July 2009

Published: 13 July 2009

BMC Neuroscience 2009, I0(SuppI I):PI90 doi:I0.II86/I47|-2202-I0-SI-PI90

This abstract is available from: http://www.biomedcentral.com//47I-2202/I0/SI/PI90

(C) 2009 Purswani et al; licensee BioMed Central Ltd.

\section{Background}

Deep brain stimulation (DBS) has become an increasingly used clinical therapy for several neurological conditions [1]. However, it is currently impossible to directly measure the distribution of the stimulus in the patient's brain surrounding the implanted electrode, and as a result computational models in the form of finite element models coupled to axon cable models for predicting the volume of tissue activated have proved useful for visualizing stimulation effects. The use of such unconnected axon models, however, relies on the debatable assumption that the excitation of efferent fibres is the functional effect of DBS. quantifying the VTA using anatomically accurate neuronal models as an alternative can provide further clues about the mechanism of DBS.

\section{Methods}

For this study, we focused in projection neurons in the subthalamic nucleus (STN), a common target for the treatment of Parkinson's disease. used results from a finite element electric field model [2-4] which provided the extracellular potential as a stimulus for a range of multicompartment models, starting with myelinated axons [5] and followed by the subthalamic projection neurons of increasing complexity [6].

\section{Results}

Our results show that the estimation of the volume of tissue activated is strongly dependent on the type of neuronal model coupled to the FEM results. In response to a 1
V amplitude extracellular pulse, unconnected myelinated axon models up to $4.5 \mathrm{~mm}$ away from the electrode fire action potentials at the same frequency as the stimulus. However, for the same stimulus, none of the model STN cells fired at the stimulus frequency, and only cells within $1 \mathrm{~mm}$ of the electrode fired at all.

\section{Discussion}

In agreement with previous work [5], the prediction of the VTA using cable models of unconnected axons and defining activation as generating action potentials in a 1:1 ratio with the stimulus frequency, provided a convenient way of comparing stimulation parameters. However, the responses of the subthalamic projection neurons, with more complex morphologies and membrane dynamics provide more detailed information about the possible mechanisms underlying the observed improvement in patients' symptoms.

\section{Acknowledgements}

This study was supported by a grant from the Medical Research Council of the UK (Grant ID: 785I2).

\section{References}

I. Dostrovsky JO, Lozano AM: Mechanisms of deep brain stimulation. Mov Disord 2003, I7:S63-S68.

2. Yousif N, Bayford R, Bain PG, Liu X: The perielectrode space is a significant element of the electrode-brain interface in deep brain stimulation: A computational study. Brain Res Bull 2007, 74:361-368.

3. Yousif N, Bayford R, Wang S, Liu X: Quantifying the effects of the electrode-brain interface on the crossing electric currents in 
deep brain recording and stimulation. Neuroscience 2008, | 52:683-9|

4. Yousif N, Bayford R, Liu X: The influence of reactivity of the electrode-brain interface on the crossing electric current in therapeutic deep brain stimulation. Neuroscience 2008, 1 56:597-606.

5. Butson CR, Mclntyre CC: Tissue and electrode capacitance reduce neural activation volumes during deep brain stimulation. Clin Neurophysiol 2005, I I 6: I- I I.

6. Gillies A, Walshaw A: Membrane channel interactions underlying rat subthalamic projection neuron rhythmic and bursting activity. J Neurophysiol 2006, 95:2352-2365.

Publish with Bio Med Central and every scientist can read your work free of charge

"BioMed Central will be the most significant development for disseminating the results of biomedical research in our lifetime. "

Sir Paul Nurse, Cancer Research UK

Your research papers will be:

- available free of charge to the entire biomedical community

- peer reviewed and published immediately upon acceptance

- cited in PubMed and archived on PubMed Central

- yours - you keep the copyright 